Please do not remove this page

RMIT

UNIVERSITY

\title{
A spiritual corporate awakening: Transcending beyond traditional corporate philanthropy with design thinking
}

Andrawes, Ledia; McMurray, Adela

https://researchrepository.rmit.edu.au/esploro/outputs/9921862695901341/filesAndLinks?institution=61RMIT_INST\&index=null

Andrawes, L., \& McMurray, A. (2015). A spiritual corporate awakening: Transcending beyond traditional corporate philanthropy with design thinking. In Corporate Social Responsibility in Developing Countries: A Development-Oriented Approach (pp. 204-220). Greenleaf Publishing.

https://researchrepository.rmit.edu.au/discovery/fulldisplay/alma9921862695901341/61RMIT_INST:Resea rchRepository

Document Version: Accepted Manuscript 
Thank you for downloading this document from the RMIT Research Repository.

The RMIT Research Repository is an open access database showcasing the research outputs of RMIT University researchers.

RMIT Research Repository: http://researchbank.rmit.edu.au/

\section{Citation:}

Andrawes, L and McMurray, A 2015, 'A spiritual corporate awakening: transcending beyond traditional corporate philanthropy with design thinking' in D. Jamali, C. Karam and M.

Blowfield (ed.) Development-Oriented Corporate Social Responsibility: Volume 2, Greenleaf Publishing, Sheffield, United Kingdom, pp. 1-17.

See this record in the RMIT Research Repository at:

https://researchbank.rmit.edu.au/view/rmit:35951

Version: Accepted Manuscript

Copyright Statement: (c) 2015 Greenleaf Publishing Limited

Link to Published Version:

https://books.google.com.au/books/about/Development_Oriented_Corporate_Social_Re.html? id=Ab4yDAAAQBAJ\&redir_esc=y 


\title{
A spiritual corporate awakening
}

\section{CSR partnerships which transcend beyond traditional corporate philanthropy in developing} country contexts

\author{
Author One \\ Ledia Andrawes \\ Global Programs Director \\ ThinkPlace Foundation \\ Mezzanine Level, 55 Wentworth Ave Kingston \\ ACT 2604 Australia \\ Tel: +61 40316727 // +25470622 473 \\ Email: ledia@thinkplace.com.au
}

Ledia Andrawes is ThinkPlace Foundation's Global Programs Director, having worked with many public and private organizations to create innovative services in the health, immigration, financial services, agricultural, and renewable energy spaces across Australia, Ghana and Kenya. Ledia is also doing her dissertation on design thinking in development through RMIT (Melbourne, Australia).

\section{Author Two}

Professor Adela McMurray PhD

Deputy Head Research \& Innovation

School of Management

College of Business

RMIT University

445 Swanston Street Melbourne

Victoria 3001 Australia

Tel: +61 399255946

Email: adela.mcmurray@rmit.edu.au

Professor Adela McMurray, $\mathrm{PhD}$, has academic and industrial experience in manufacturing and service industries. She has over 90 publications, won best author and teacher awards, research grants totaling over $\$ 2.5$ million, is an editorial advisory board member for numerous journals and Chairs the International Theme Committee at the US Academy of Management. 


\section{Contents}

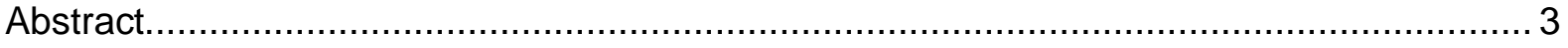

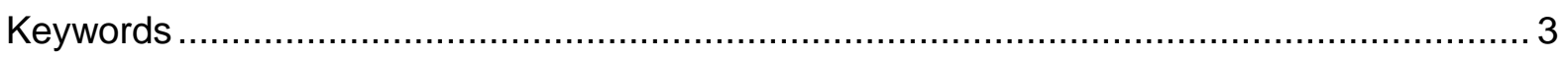

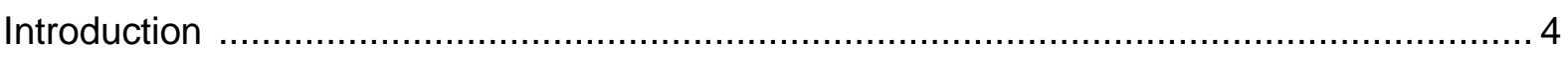

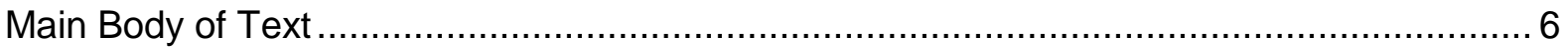

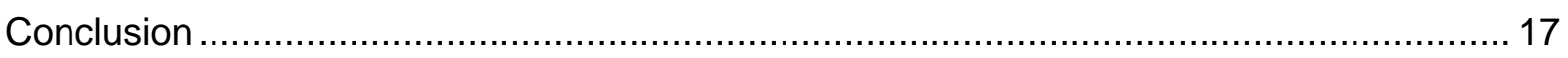

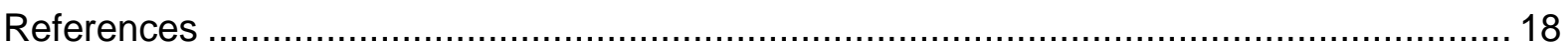




\section{Abstract}

This chapter explores the spiritual corporate awakening that is taking place at the intersection of design thinking and international development. The content is relevant to designers, development practitioners, donors, and any other actors involved in the design of new futures for marginalized populations residing in developing country contexts.

Consolidating an in-depth literature review with applied field experience, we explore how greater social accountability and participatory development is being developed through new partnership models between design thinking firms and more traditional international development sector organizations.

Theory is demonstrated with real life examples and vignettes written from a practitioner's insights and experiences. The narrative of experiences from Ghana, Kenya and Tanzania present reflections which were documented over a period of 18 months. These are comprised of readings, combined with observations and conversations with people working in design thinking and international development in these countries.

In the first instance, understanding the criticisms of conventional, top-down strategic management approaches in international development provided the foundation upon which to add the layers of inthe-field observations and narratives with designers and development practitioners working in the sub-Saharan Africa. These insights were gathered through manual analysis of the applied case studies which are presented as vignettes and provide a frame for future research in this emerging area.

\section{Keywords}

Design thinking, Human Centered Design, Innovation, CSR, Corporate Social Responsibility, Poverty, Participation, Accountability, International Development, sub-Saharan Africa, Ghana, Kenya, Tanzania 


\section{Introduction}

Firstly, this chapter explores current criticisms relating to international development management. Next it defines the concept of design thinking and its place in the international development landscape. Then it identifies examples of design thinking in developing country contexts being predominantly focused on tangible product innovation, with little emphasis on the role of design thinking at the strategic management levels within international development sector organizations. Throughout the chapter, there are three case examples presented as vignettes that are derived from a thriving partnership between the design thinking firm, ThinkPlace, and forward-looking international development organizations, Grameen Foundation and Concern Worldwide. The case examples are used to demonstrate how these partnerships are leveraging a spiritual corporate awakening within the intersection of design thinking and international development. This transcendence beyond conventional affiliations of financial donations and staff volunteer time in corporate philanthropy has the potential to redefine a new kind of Corporate Social Responsibility (CSR), a development-oriented one - with a different role and potential impact - in both developing country contexts as well as within the for-profit organizations which enable it.

There is increasing pressure on global resources and funding availability, governments, multilateral/bilateral organizations, and non-governmental organizations (NGOs) who administer development programs. There has been growing criticism of such organizations. Particularly the ineffectiveness and unsustainability of their traditional approaches to development management, which have had limited impact on marginalized populations in developing country contexts (Madon 1999, O'Dwyer and Unerman 2007). These approaches are based on linear, cause-effect models of change in human systems (Britton 2005, Dennehy, Fitzgibbon et al. 2013) that have ensured 'functional accountability' - which is accountability that is directed to donors more so than beneficiaries, and on project needs more so than human needs. Whether intentional or not, this has resulted in limited beneficiary participation in defining the need or solution possibilities early enough to really guide strategic decisions which directly affect them.

The issue at hand lies in the 'technocratic' character of the current development approach, whereby 'solutions' to development 'challenges' are considered to be best handled by the development 'expert' (McGregor and Burns et al. 2012). This is seen as contributing to mistrust in the effectiveness and relevance of development organizations. This confirms the need for more collaboration and mutual learning, especially between development beneficiaries and the organizations which are working for them. A participatory, bottom-up approach is essential for ridding Africa of its aid-dependency. There is an argument to be made about how development thinking can implement more from design thinking. Design thinking has reinforced the value of empowering people and communities to engage in decisions that work for them rather than being recipients of external and sometimes misaligned solutions to them. 
Increasingly today, 'design thinking' is seen as a vehicle for the design discipline to contribute to innovation practice across other disciplines, especially in strategic management circles as an approach to dealing with complex realities (Johansson-Sköldberg, Woodilla et al. 2013). There is no agreement yet among prominent voices in the discourse about its exact definition and how to go about practicing it. According to Tim Brown on IDEO's website, "design thinking is a human-centered approach to innovation that draws from the designer's toolkit to integrate the needs of people, the possibilities of technology, and the requirements for business success." Based on this definition, design thinking offers organizations and people who are not traditionally design-trained a new way to address complex realities like designers would. Design thinking can be the means to the end - the disciplined set of actions that leads to a desired end state - of a new interaction, product, service, process, policy (Dorst 2011, Brown and Katz 2008) or even a world without extreme poverty.

ThinkPlace is a design thinking firm who's CSR strategy is no longer about donating money to local charities or sponsoring a table at an event, or asking employees whether they want to spend a day volunteering their time to do some pro-bono work for an NGO. This small Australian business is now leveraging their design thinking methodology, toolkits and talent to a more development-oriented CSR approach. With a growing desire among its designers to contribute more meaningfully in addressing some of the world's most 'wicked problems' - like poverty alleviation - what is emerging is a corporate social awakening within creative economy organizations like ThinkPlace. This aligns strongly with Buchanan's 2001 work on the designer's role to advance human dignity. Developmentoriented design firms like ThinkPlace, are changing their identities and strategies to respond to this spiritual awakening their employees are presenting with by redefining their role in developing country contexts. What does this offer development organizations? What opportunities emerge when development organizations collaborate with design firms in applying human-centered ideologies, tools and techniques to understand, communicate and address the needs of the people they seek to benefit? What role can development-oriented design firms have in the international development sector's evolution and what are the implications of this on their own identities and CSR strategies?

Bringing together analysis and insights from Design, Business and Development bodies of literature, as well as in-the-field observations and narratives with designers and development practitioners, this chapter puts forward the case for the integration of design thinking in all aspects of development management. This chapter aims to identify how the development sector can achieve greater social accountability and beneficiary participation through collaborations between development organizations and development-oriented design firms. We will also look at the implications of the above on the CSR strategies of these design firms working in developing country contexts. 


\section{Main Body of Text}

\section{Setting the scene: why is this important?}

Across Africa, there are many pieces of expensive medical equipment lying around with no one trained to use them (Perry and Malkin 2011), pump wells lying idle because a part unavailable locally has broken down (AE 2011), and education programs that fail to leverage the cultural context and so don't achieve a sustained impact (Schweisfurth 2011). Then there is the greatest issue of all: traditional approaches to charity reinforce peoples' reliance on others to help them - rather than building a notion that they are able to help themselves (Moyo 2009). Other criticisms have included that beneficiary countries must use overpriced goods and services from donor countries and aid amounts are dwarfed by consultant fees re-routing that aid money back into donor economies. This can be very destructive on the economy of the beneficiary communities and contribute to more poverty in the long term. This is not to say that all development work is bad. There are many programs that are having a substantial impact on local communities - these programs build capacity and offer solutions based on shared value rather than long-term dependency for beneficiaries. So perhaps it is not development in and of itself that is the issue- it is how it is designed, organized, distributed and implemented that holds the answer (Collier, 2007).

Organizations who administer development programs are needing to evolve in order to meet mounting pressures and shifting complex realities. There is little agreement on how to classify international development organizations (Fisher 1997, Vakil 1997, Doh and Teegen 2002, Martens 2002); the focus of this chapter is on development-oriented NGOs (NGDOs), who will also be interchangeably referred to as 'development organizations'. These organizations have chosen to continue with existing ways of working, despite their failure to deliver on the promise of sustainable economic growth and poverty reduction (Moyo 2009). In many respects, the development sector needs transforming, not scrapping (Collier 2007). This suggests there needs to be a more nuanced approach to the management of development initiatives, thus the significance of this chapter.

\section{From functional accountability to social accountability}

Perhaps due to the evolving role of development organizations over the years, critical questions are being asked of their accountability and performance (Edwards and Fowler 2002; Slim 2002). Donors, whether public or private, tend to focus on 'functional accountability', which is short-term in orientation, and looks at prioritizing reporting on resources, resource use, and immediate impacts (Ebrahim 2003; Edwards and Hulme 2002; Najam 1996). Dependence on donors for survival has increased the pressure on development organizations to prioritize this upward, functional accountability, at the expense of social accountability, even though there are many instances in the literature which call for greater social accountability toward key beneficiary constituencies (Edwards and Hulme, 2002; Cronin and O'Regan 2002; Ebrahim 2005; Najam 1996). In practice, however, 
development sector accountability to beneficiaries and other stakeholder groups other than donors seems quite weak (Edwards and Hulme 2002; Najam 1996). Edwards and Hulme (2002) contend that development organizations need to "improve significantly on their current performance in evaluating learning, institution building and levels of participation" for social accountability to become more mainstream.

Despite the international and cross-cultural nature of development organizations, most have adopted management practices from a western understanding of organizations and cultures (Britton 2005). This has brought with it an "audit culture of imposed tools, frameworks and reporting procedures" (Angus 2008). It is a risk averse mindset that insists on a level of surety of output demonstrated in logical frameworks, cause-effect analysis, results based reporting and priority on output - as it happens, it does not value or reward attributes of experimentation, action learning, risk taking and creativity (Angus, 2008). These linear approaches expected by the donors do not allow the space for strategic management styles that encourage innovation, collaboration and participatory ways of working (Tacchi, Lennie, \& Wilmore, 2010). Yet, development organizations continue to follow this linear, project model - mainly because it is the preference of their donors, on whom they depend on for survival. Over the years, however, there has been growing critique and unease with the method. Finding themselves vulnerable to criticisms about the nature of accountability towards their beneficiaries, forward-looking development organizations are increasingly looking for ways to increase their impact, effectiveness and accountability (Dennehy, Fitzgibbon et al. 2013).

We propose design thinking as offering an alternative to the current status-quo. Through participant observations during, and semi-structured review interviews post project engagements in the field with development actors, these vignettes were constructed from the reflections of designers and development managers working on health and financial sector development projects in Ghana, Kenya and Tanzania.

\section{Vignette \#1:}

Ghana is a developing country with high rates of morbidity and mortality coupled with notable differences between rural and urban settings. The maternal mortality ratio of Ghana is estimated at 451/100 000 live births. According to the Demographic and Health Survey (DHS), the under-5 mortality rate in rural Ghana it is as high as 90 deaths per 1000 live births. Coverage of skilled birth attendance is $82 \%$ in urban Ghana compared with $43 \%$ in rural Ghana. In the upper West Ghana villages of Saawie, Chebongu and Dabo, improving health outcomes for women and children depends not only on the availability of maternal, newborn and child health $(\mathrm{MNCH})$ services, but on overcoming significant cultural, economic and logistical barriers to accessing them. In early 2014, ThinkPlace joined the ProNet North and Concern Worldwide Innovations team to co-design a cultural change process to incentivize prioritizing prenatal and antenatal care, and to engender a community-wide behavioral 
change in the long term. The basis for the innovation was to employ a human-centered design thinking approach which involved building a deep sense of empathy throughout the research process in order to understand interdependencies between the communities' social, economic and cultural contexts and their capacity to access health care. This emphasis on bringing in the voice of the user in the planning processes of the program enabled the development team to devise a cultural change process that was unique to each community and which drew upon and leveraged the existing social and cultural structures.

"One of our biggest challenges was to try to get the real stories rather than the ideal stories" reflected a designer. There was a known tendency for participants to tell the researchers what they thought they wanted to hear, rather than relating their actual lived experiences. The local NGO staff highlighted that a sensitive approach would be needed in order to establish the trust necessary for participants (especially women) to be willing to share their real stories, while traditional hierarchies within the village would need to be respected in order to appropriately and effectively engage leadership. It was also important to respect men's social status and ensure they were fully engaged in the process of establishing targets for changed behavior. These considerations were embedded in the research planning and processes. The team conducted ethnographic research through interviews and observations, engaging with the core figures influencing women's health, including village leaders, mothers-in-law, experienced women, young women and men (see below figure 1).

Figure 1: Influences on women's health in rural Ghana (ThinkPlace, 2014)

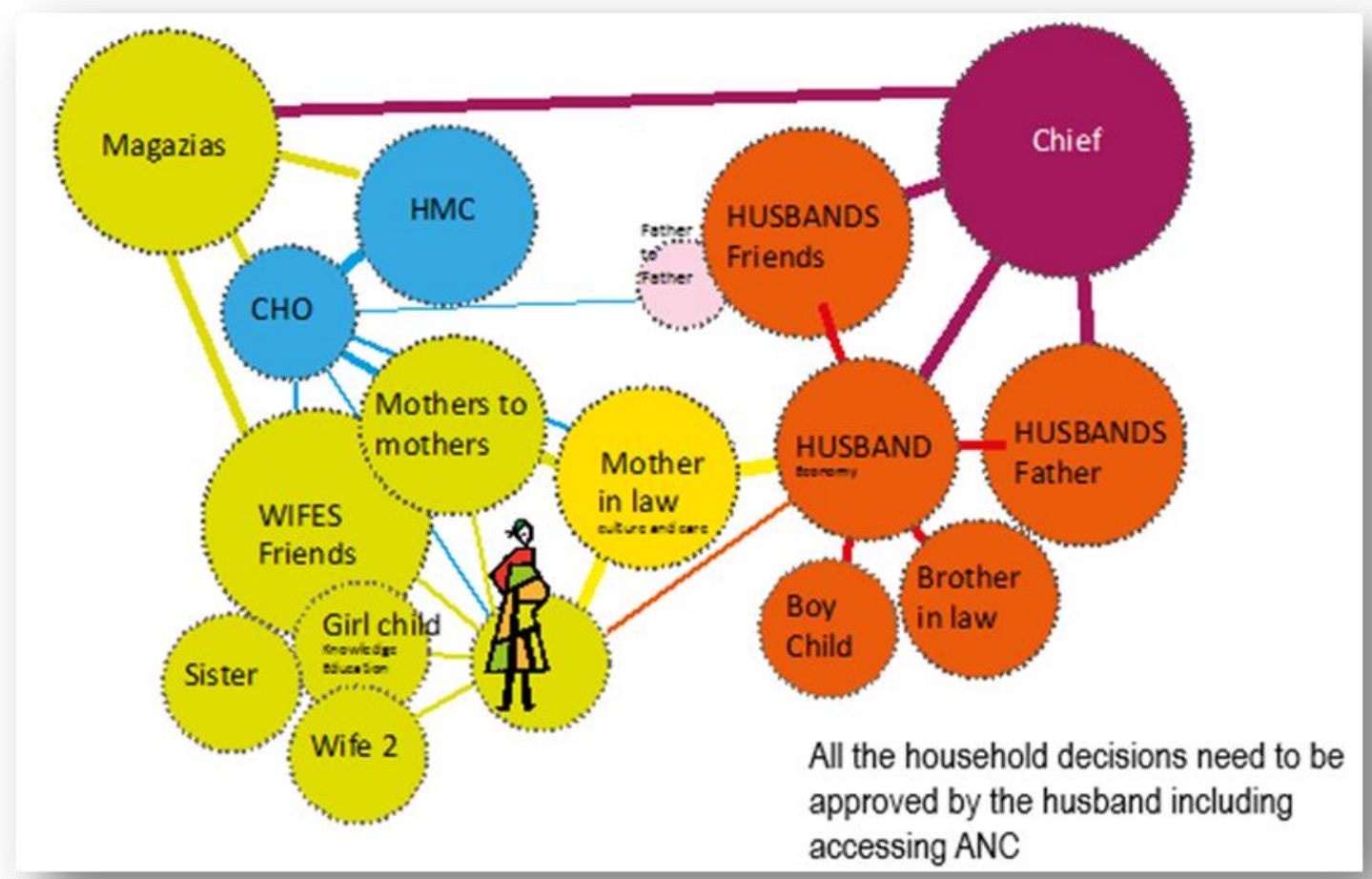


The participants were encouraged to tell their stories in their own words which enabled participants to emphasize the details and challenges that they considered to be most important. Embedded within this project was a deep understanding of the men and women involved and their context. Utilizing a design thinking approach facilitated leveraging the needs, desires and capacity of the beneficiary communities in framing their issues and possible futures. This resulted in an action research approach to cultural change that was deeply innovative in its capacity to leverage existing social structures and practices to create fundamental change. This experience illustrates how innovation to create change is not limited to the introduction of the new products, but can arise from a process of design and research which is fundamentally about bringing the voice of the user to the development planning process.

According to Richard Buchannan (2001), "human-centered design is fundamentally an affirmation of human dignity. It's an ongoing search for what can be done to support and strengthen the dignity of human beings." This suggests that design thinking has a more significant role to play than just developing new products and services people can use, or like to use. It now has an extended responsibility to advance someone's dignity by offering a way of thinking about the world (Buchanan 2001). As this example demonstrates, there is plenty of scope for greater social accountability and affirming human dignity in development programs through introducing more human-centered ways of working. In addition to this, the degree of complexity and meaningfulness of the problem instigated a heightened energy and engagement from the design team. This heightened energy and engagement illustrates how the spiritual corporate awakening is manifesting itself in the creative economy in Ghana.

\section{From conventional management thinking and towards design thinking}

Traditional approaches to management which have dominated business for decades are inadequate to address today's more complex challenges (Jenkins 2010). We are now confronted with a very different set of wicked problems, which the analytical thinking toolkit is inadequately equipped to address. The problems with traditional approaches to strategy making have been criticized in the literature at length. They include: "the attempt to make a science of planning with its subsequent loss of creativity, the excessive emphasis on numbers... and standardized inputs and formats at the expense of substance" (Liedtka 2000). Drawing on the proposition that development practice is a knowledge industry operating in contexts of significant sociocultural diversity and complexity, Jenkins argues that an alternative thinking toolkit and knowledge system is needed. Design thinking offers an alternative approach with processes that are more widely participative, more dialogue-based, and aimed at invention and learning, rather than control (Liedtka 2000).

Taking a design thinking approach differs from traditional ways of doing things, in that instead of starting by defining strategy, it starts with a more exploratory tone, opting for immersive research to 
discover opportunities for innovation in strategy (Holmlid and Evenson 2008). There are benefits to this, as user needs become more evident, more understood, this in turn informs the problem definition and framing by incorporating the voice of the user. Of most value for beneficiaries of development initiatives in sub-Saharan Africa, however, design thinking offers the perspective for strategy making as a process of iteration and experimentation, with "sequential attention to idea generation and evaluation in a way that attends first to possibilities before moving onto constraints" (Liedtka, 2000; Liedtka, King, \& Bennett, 2013).

There is a growing collection of experiences in applying design thinking methods and tools in developing country contexts, the literature points to many powerful examples of design thinking's contribution to poverty reduction. This, however, has been limited to either of two things, (1) the production of goods and (2) the consumption of goods (Thomas, 2006). For example, the design firm IDEO, worked with KickStart to create the MoneyMaker Pump, a small but powerful small-acreage irrigation pump with hard-to-ignore impact: Since 1991, the pump contributed to the creation of 64,000 new businesses, generating $\$ 79$ million a year in new profits and wages. Another exemplar is the LifeStraw, a portable water purifier that has helped prevent common water-borne diseases. Forbes magazine has called it one of the "ten things that will change the way we live." This is great, but to some designers out there, the real challenge is to move from intermittent cases of product successes to a more systemic approach to strategy making that values the voice of the user more and more. Examples of design thinking contributing to broader system, organizational, and strategic management practices in development organizations are, to date, not evident in the academic literature. That is not to say it is not happening in practice. Just as it has in business, design thinking has emerged to position itself as a negotiator of value, as facilitator of thinking, as visualizer of the intangible, as navigator of complexity and mediator of stakeholders (de Mozota, 2013), and no longer just as a process for traditional product development innovation (Liedtka 2014).

\section{From beneficiaries to co-designers}

Through incorporating co-design methodologies in its CSR partnerships with international development organizations, ThinkPlace is navigating and elevating the words, experiences and ideas of the beneficiary populations themselves to the boardroom tables of the development organizations who are serving them. For ThinkPlace, development-oriented CSR means actively involving people to identify and address the issues that marginalize them to effectively remove the constraints on their development (Dennehy, Fitzgibbon et al. 2013). Grau Serrat from D-Lab at MIT says "the emphasis has shifted, more from designing for poor people to designing with poor people, or even design by poor people." "Creative capacity-building" is the term used to describe the fostering of local innovation by providing training, resources, information, tools and inspiration to marginalized populations. There are obvious benefits for the people whose lives we are trying to improve if the approach employed engages them in the problem framing as well as and decision making during the solution design. This 
has become a mantra of development-oriented design firms working with marginalized populations.

\section{Vignette \#2}

A participatory approach to design an alternative future for marginalized population groups seems like the obvious way forward. In Kenya, $75 \%$ of the population derives its livelihood from agriculture both directly and indirectly. A larger portion of these farmers, specifically smallholders, are still excluded from formal financial services primarily because the products in place are not tailored to their needs. About $21 \%$ of Kenya's GDP is from the agricultural and forestry sector, yet despite its importance, the sector suffers from low productivity levels coupled with chronic under-investment. The government's 2013/14 budget allocation of 4\% (Ksh38.1bn) is relatively low when compared to African Union's target of $10 \%$. ThinkPlace worked with Grameen Foundation and a local commercial bank, Jamii Bora Bank, in understanding the drivers of rural and peri-urban smallholder farmers through strongly grounded ethnographic design research and facilitated co-design workshops. The aim was to use the information gathered in the field to create a simple and innovative financial solution that meets the needs of low-income smallholder farmers while growing the agribusiness portfolio for the bank. The time spent in the field, shadowing, speaking to and understanding the local realities, needs, preferences, cultural context, constraints and touch points of the smallholder farers resulted in a strong, grounded empathy for the thousands of decisions which follow in the planning, design and implementation of the project. The research identified that there is no such thing as a 'typical' farmer. Profitability is not correlated to land size, but is based on relative access to information, finance and markets. The unbanked smallholder farmer segment is displaying needs beyond traditional access to finance. Going beyond assumptions and conventional management approaches has provided a strong foundation for innovative solutions which go well beyond the status quo and have a real impact on the bank's customers.

The creation of personas (see figure 2 below) to inform a fit-for-purpose and user-oriented solution have proven to be useful artefacts to pull up the voice of the "user" and maintain that voice throughout the pitching, planning, design, development, implementation and scaling-up phases - 
Figure 2: Personas representing intrinsic characteristics of smallholder farmers in Kenya (ThinkPlace, 2014)

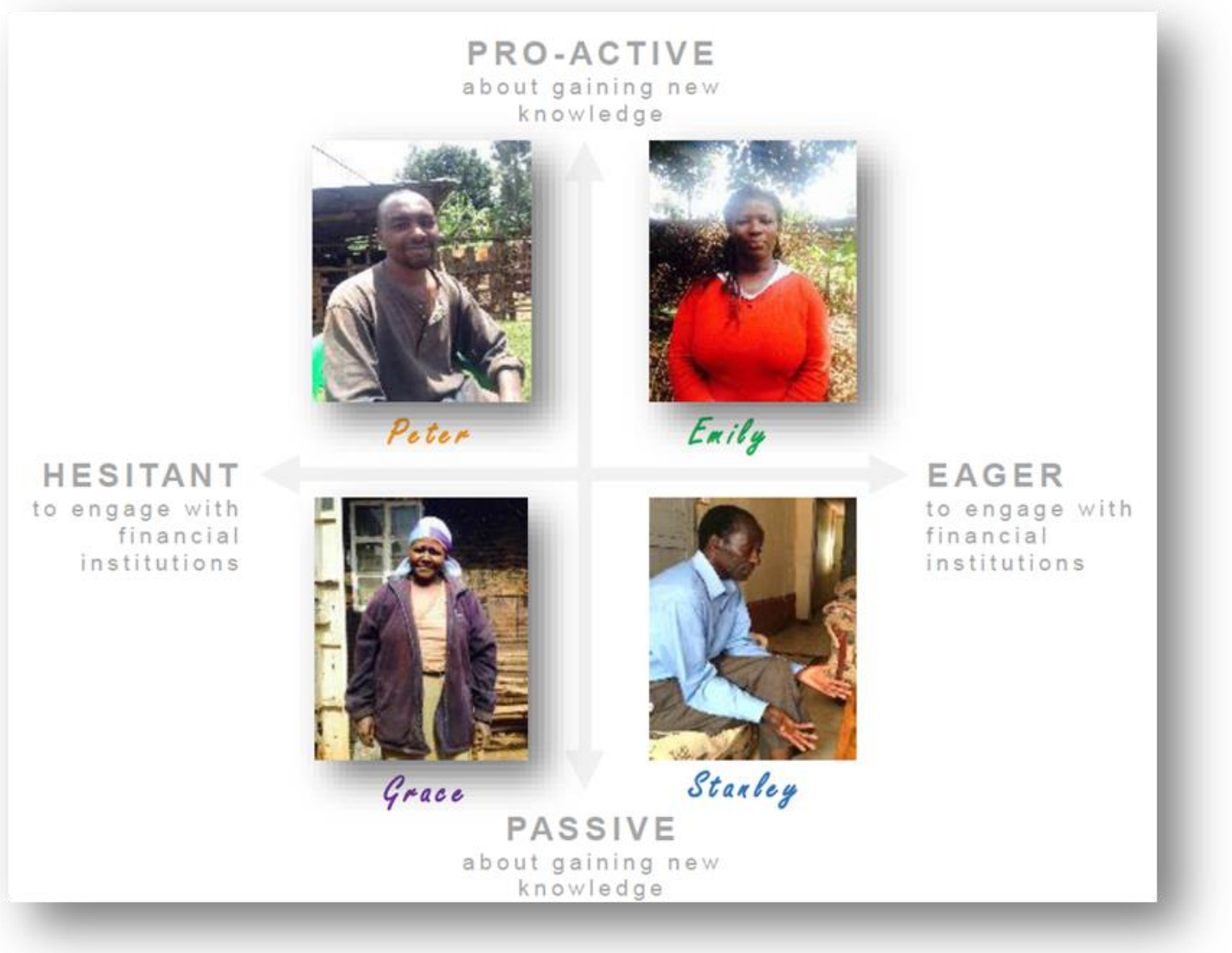

Referring to the evolving role of designers, "we shift our perspective from the massive totality of the system to the pathways of individual human experience" (Buchanan 2004). The pathway technique (see figure 3 below) is an interesting, engaging, creative and expressive way to tackle development-related challenges. Most of these challenges are complex, have many dimensions, and are not easily solvable. If we take a human-centered approach and consider a person's experience through this complexity, we can develop a pathway and then we can start to make real, practical and meaningful changes to that system. Constructing a user pathway forces an organization to take an outside in view, rather than an inside out view. Whilst this sounds like a simple and logical concept, it is much more difficult in practice. It is much easier to think from the perspective of our own organizational structures, business processes and technologies. A well-constructed user pathway allows us to develop empathy and a real understanding of the user's experience in an organizational system. If we can get into the user's space and think about the decisions we have to make from their perspective, we are more likely to plan, design and make things which the user finds useful, useable and desirable. User pathways are helpful tools for dealing with complexity and facilitate dialogue with end users, the pathway below demonstrates the cash flow pathway of one of the personas represented earlier.

Figure 3: Pathway through a of smallholder farmer's annual cash flow (ThinkPlace, 2014) 


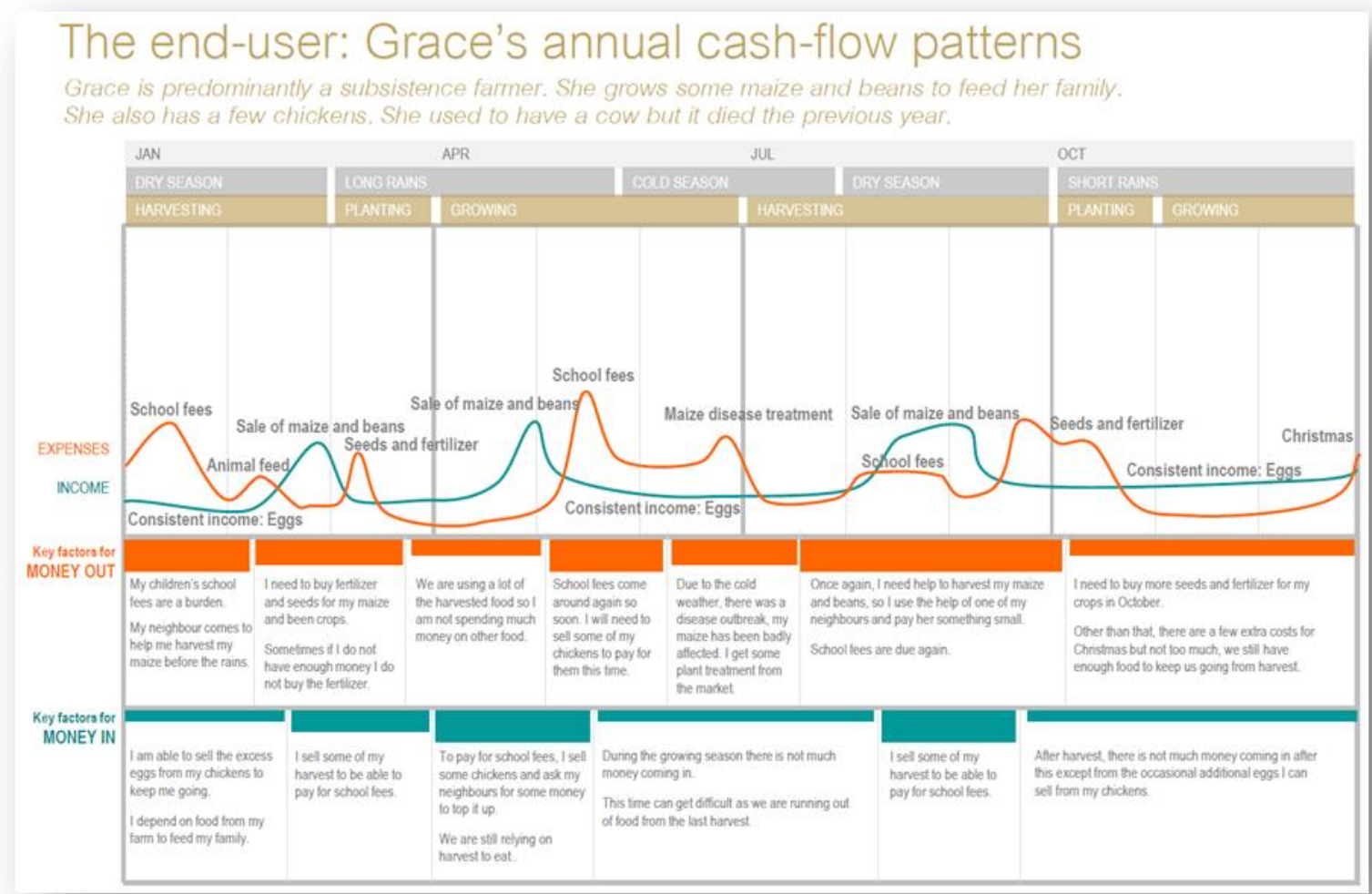

(Note: any names mentioned in Figure 3 have been changed in order to retain anonymity)

This participatory design ideology has been used by design firms for decades now. However, design firms are increasingly looking at this ideology and its place in their CSR initiatives, extending them beyond donations and employee volunteer days to "give back." Instead, these organizations are looking inward, curiously, as to how they might apply their people and their know-how to build creative capacity and address specific development challenges that align with not only their business strengths, but also their employees' ambitions. Design thinking firms who transcend beyond traditional giving not only have a significant role to play in the knowledge and creative economies of developing countries, but also internally in responding to the corporate spiritual awakening within. Traditional CSR approaches are continuing to be challenged at design thinking firms like ThinkPlace.

\section{The spiritual awakening at the intersection of design thinking and development}

Although it has been argued in many texts that the imperative of design thinking for social good is not a new one; it is in fact a fairly unique time where "we are in the midst of an immense, worldwide movement - for which there is no name, and for which there is no central organization," as Paul Hawken (2007) puts it. He goes on to discuss how individuals at all levels are creating meaningful change, decentralized yet united in their quest for good as part of a planetary "immune response" which is translating into some spiritual-type awakening. This awakening is not just at an individual level, it is becoming increasingly reflected in corporations through their evolving CSR strategies and 
demands for a more development-oriented perspective. According to Porter and Kramer (2011), customers, employees and a new generation of young people are asking businesses to step up. Businesses are being pressured into reshaping their purpose from delivering dividends to shareholders to delivering shared value to many more. Today, we also stand at a critical point in human history, that of peak wealth, alongside growing social inequality and poverty. Designers are not innocent bystanders. One of the challenges is that $90 \%$ of the world's designers focus their energy on solutions to the problems (or non-problems) of the richest $10 \%$ of the world's consumers. The corporate spiritual awakening taking place among designers, specifically, has the potential to reverse this ratio and reach the other $90 \%$ (Polak 2008).

\section{Vignette 3}

ThinkPlace recently worked with CGAP and Grameen Foundation to deliver an innovation camp that brought together innovators from private sector organizations from all over the world. The goal was to consider how delivering products for the mass market in developing countries could be done more successfully, that is, with sustainability and scalability as key. There were over forty innovators sharing learnings and ideas from banks, telecommunication companies, NGOs, funders and design thinking firms who collaborated during this event in Dar es Salaam, Tanzania (see figure 4 below).

Figure 4: Stories of innovation successes and failures from an innovation camp in Tanzania

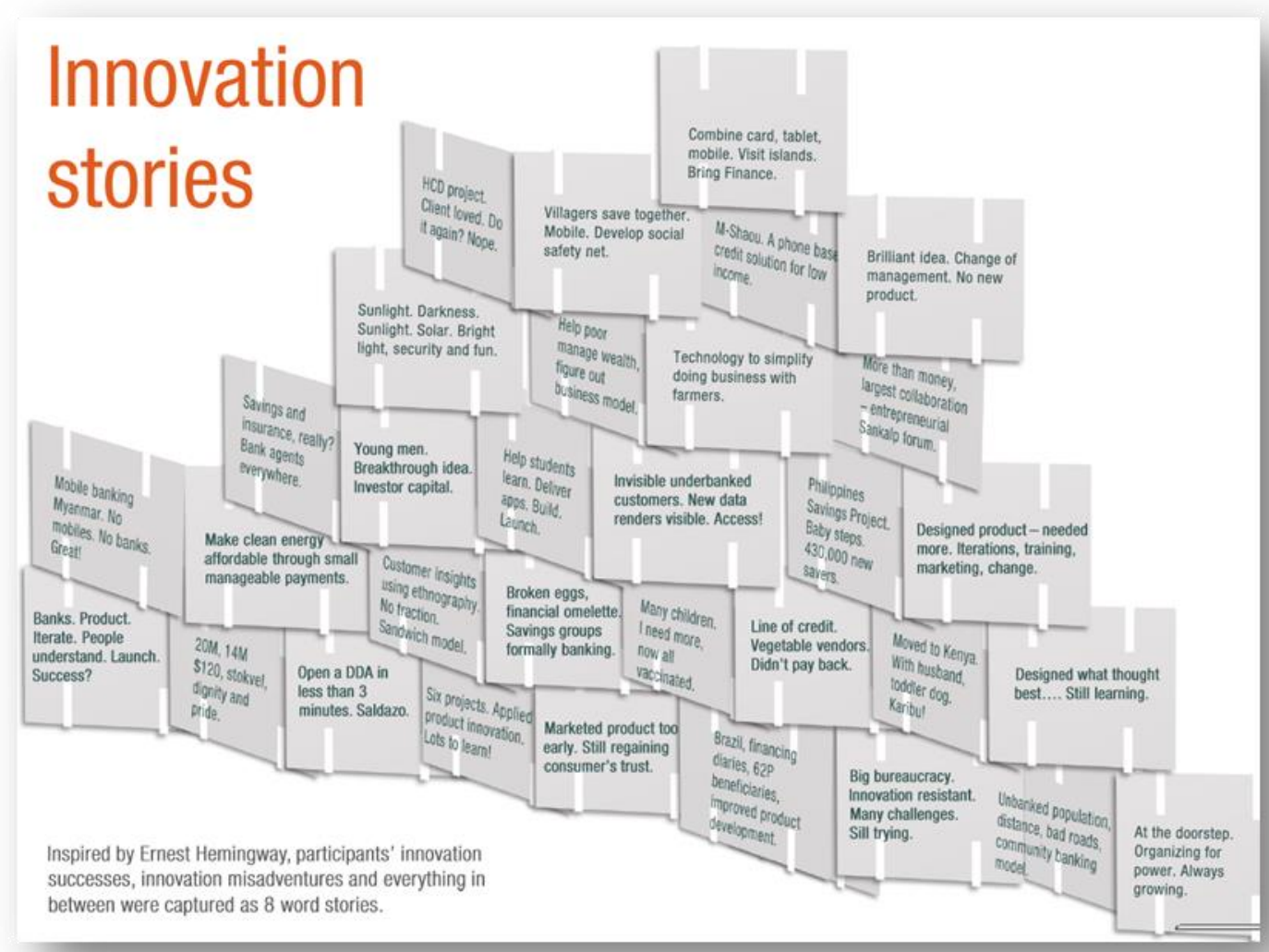


The result was a crop of big ideas to help these organizations better deliver innovations for the base of the pyramid. Arguably design thinking provides the development sector a proven method and a set of tools to help achieve its stated goals of more local, transparent, resilient and less dependent communities where beneficiaries take control of their own agendas (Johnson \& Andersen, 2012). While design thinking may not eliminate global poverty on its own, it may just have the potential to make a significant impact in poverty reduction by contributing to a new way of listening, collaborating and engaging with people and markets for development progress.

The interesting and intersecting space being tested through various partnership models between design thinking firms and development organizations is particularly significant to both development organizations and their donors as offering an alternative approach that meets growing expectations in a complex environment. A development-oriented CSR approach could mean many things in this context. It could mean that a business is aligning their CSR to what the development sector needs over and above what its own business prioritizes. It could mean a business will focus its CSR initiatives on skills transfer and creative capacity building rather than just product development and consumption in developing country contexts. It could mean a business is making its internal IP accessible to the international development sector to help strengthen organizations and build emerging markets from within. In any case, 'development-oriented' CSR puts the needs of international development organizations and the people they serve at the core of a for-profit organization's CSR strategy, even if it does come at the cost of profit-making.

Beyond traditional corporate social responsibility, there is evidence that design thinking firms are now looking to invest in this corporate spiritual awakening in order to cultivate the next generation of knowledge and creative capacity in developing countries. The world's problems are more complex and necessitate collaboration and co-design techniques. Solutions thought up in ivory towers by experts disconnected from the problems of the people they seek to benefit will not work. Through partnerships between design thinking firms and the development sector, there is potential for putting real rigor and discipline behind the rhetoric of being participatory and inclusive. However, there are some structural barriers to this at present. The business models of most design firms were built to serve commercial clients, and hence, for many development organizations, the key barrier to working with design firms has been a financial one. Design thinking firms and development organizations need to work on new, sustainable business models to move this forward. Based on the enthusiasm received from development organizations it has partnered with to date, ThinkPlace is testing out different ways for supporting the development sector which do not necessitate profit-making as key. There's no lack of enthusiasm and excitement for working in this area by designers, with a redefined CSR strategy of being more development-oriented posing as one way for them to interface with realworld challenges and meaningful work. 


\section{Reflections on development-oriented CSR}

In the vignettes discussed earlier, designers' supported development managers to listen to, interpret and represent beneficiary needs, their voices, their values, and enable empathy to be at the center of development decisions. This qualifies as development-oriented CSR as it goes beyond the typical business-oriented CSR that prioritizes self-interest in its contribution towards development. Instead, these examples focused more on developing tools for more effective ways of working (Buchanan 2001, Brown and Katz 2009, de Mozota 2013, Lockwood 2013, Liedtka 2014) between development organizations and their beneficiaries to achieve greater social accountability and participation, with no tangible business interest being prioritized. The social corporate awakening which is driving design thinking firms to take this development-oriented approach poises a significant opportunity for development organizations to continue their evolution of learning, innovating and optimizing their effectiveness.

For some time now, there have been growing concerns about the relevance of current measures of development performance. The conclusion of the Sarkozy Commission Report (2009) supports the idea that those organizations concerned with genuine human-centered development need to shift their focus from narrow measures of economic progress to broader measures of human wellbeing (Stiglitz and Sen, et al. 2010). Until this happens, it will be difficult for the development oriented CSR initiatives of design thinking firms to be evaluated as successful or unsuccessful. Anecdotal evidence from the field supports this, human need should be depicted in terms of what is important in people's day-to-day lives in order to shape new metrics for development sector success, which would make more sense to use in evaluating these case examples. 


\section{Conclusion}

There is strong evidence to suggest that the tools used by development organizations to plan, monitor and evaluate are often inappropriate and that donor requirements for accountability are making the task at hand more difficult for development organizations. However, based on the design thinking and development bodies of literature, triangulated with practitioner's in-the-field experiences, design thinking offers a complementary, integrative and powerful way for the development sector to better manage increasingly complex realities and growing expectations. The characteristics of design thinking align strongly with what the development literature suggests as opportunities for strengthening development practices, specifically with the aim of greater social accountability and beneficiary participation. Development-oriented CSR initiatives from design thinking organizations could support the move towards collective action by development organizations, where the people who are experiencing these challenges first-hand are invited to co-produce the solutions with development agents.

The narratives presented by the vignettes clearly demonstrate how designers can play a role in developing countries beyond facilitating the production or consumption of new goods and services. The role of designers has evolved now to broader organizational and system-level problem solving. As much as design thinking has been celebrated in recent years as a strategy-making and management toolkit for business, education, government and social innovation realms; there is certainly a gap in the literature regarding its extension to international development organizations. The use of design thinking to center the voice of the user at the development organization's decision making table will have major implications for the ways in which these organizations structure themselves, raise and spend their resources, and relate to their beneficiaries. Given the absence of critical investigation and analysis on 'design thinking' and its contribution to development management for greater social accountability and participation, there is a real opportunity for future research to better understand this emerging area. "Design thinking might have its greatest impact when it's taken out of the hands of designers and put into the hands of everyone" (Brown and Katz, 2009).

Coming to terms with this need has become the underlying principle for design firms to transcend beyond conventional CSR practices and to think further about their role in more meaningful, humancentered, and creative capacity-building oriented initiatives. The implications of these organization's transition from one CSR reality to another represents a shift in mindset which is definitely worth further exploration. Along with many other service-oriented, private-sector organizations - design thinking firms, like ThinkPlace, are undergoing a corporate spiritual awakening. This is becoming an increasing trend and symbolizes a corporate transcendence beyond traditional CSR for development. These organizations are changing their values. They are changing their strategies. They are redefining CSR for development in a way which makes it more human-centered, responding to real human need and building the creative capacity of people working in developing country contexts. 


\section{References}

Permission to use illustrative examples in this paper, namely figures $1-4$, has been granted by ThinkPlace, Grameen Foundation and Concern Worldwide.

AE, T. (2011). Evaluation of Rural Water Supply Schemes in Selected Communities in Oke-Ogun Area, Oyo State, Nigeria. Global Journal of Science Frontier Research, 11(9).

Angus, K. (2008). The Development NGO-A foreign place for the peace builder, Oxford Brookes University.

Bakewell, O., \& Garbutt, A. (2005). The use and abuse of the logical framework approach. Stockholm: Swedish International Development Cooperation Agency (Sida).

Britton, B. (2005). Organisational learning in NGOs: creating the motive, means and opportunity, INTRAC Oxford.

Brown, T. and B. Katz (2009). Change by design: how design thinking transforms organizations and inspires innovation. New York, Harper Business.

Buchanan, R. (2001). "Human Dignity and Human Rights: Thoughts on the Principles of Human Centered Design." Design Issues, Massachusetts Institute of Technology 17(3): 35-39.

Buchanan, R. (2004). Interaction pathways in organizational life (pp. 54-63). Stanford, CA: Stanford University Press.

Collier, P. (2007). "The bottom billion." ECONOMIC REVIEW-DEDDINGTON- 25(1): 17.

Cronin, D., \& O'Regan, J. (2002). Accountability in development aid: Meeting responsibilities, measuring performance.

de Mozota, B. B. (2013). "Design Strategic Value Revisited: A Dynamic Theory for Design as Organizational Function." The Handbook of Design Management: 276.

Dennehy, D., M. Fitzgibbon and F. Carton (2013). "International development: exploring the gap between organisations' development policy and practice" AI \& SOCIETY:1-10.

Doh, J. P. and H. Teegen (2002). "Nongovernmental organizations as institutional actors in international business: Theory and implications." International Business Review 11(6): 665-684.

Ebrahim, A. (2003). Accountability in practice: Mechanisms for NGOs. World Development, 31(5), 813-829.

Ebrahim, A. (2005). Accountability myopia: Losing sight of organizational learning. Nonprofit and voluntary sector quarterly, 34(1), 56-87.

Fisher, W. F. (1997). "Doing good? The politics and antipolitics of NGO practices." Annual review of anthropology: 439-464.

Hawken, P. (2007). Blessed unrest: How the largest movement in the world came into being, and why no one saw it coming. Penguin.

Jenkins, J. (2010). Things can be other than they are. Understanding the limitations of current management thinking and knowledge practice for work in the development sector. IKM_Emergent, viewed, 28.

Johansson-Sköldberg, U., J. Woodilla and M. Çetinkaya (2013). "Design Thinking: Past, Present and Possible Futures." Creativity and Innovation Management 22(2): 121-146.

Johnson, B. \& Andersen, A. D. (2012). Learning, Innovation and Inclusive Development: New perspectives on economic development strategy and development aid. Aalborg University Press.

Liedtka, J. (2000). "In Defense of Strategy as Design." California Management Review 42(3). 
Liedtka, J. (2014). "Innovative ways companies are using design thinking." Strategy \& Leadership 42(2): 40-45.

Liedtka, J., A. King and K. Bennett (2013). Solving Problems with Design Thinking: Ten Stories of What Works, Columbia University Press.

Lockwood, T. (2013). "A Study on the Value and Applications of Integrated Design Management." The Handbook of Design Management: 244.

Madon, S. (1999). "International NGOs: networking, information flows and learning." The journal of strategic information systems 8(3): 251-261.

Martens, K. (2002). "Mission impossible? Defining nongovernmental organizations." Voluntas: International Journal of Voluntary and Nonprofit Organizations 13(3): 271-285.

McGregor A, Burns D, Waldman L, Watson N, \& Williamson R. Bellagio Initiative Report (2012). Human Wellbeing in the 21st Century: The Future of Philanthropy and Development in the Pursuit of Human Wellbeing - Promoting Human Wellbeing in a Challenging Global Context - Synthesis Report. Institute of Development Studies (IDS).

Moyo, D. (2009). Dead aid: Why aid is not working and how there is a better way for Africa. Macmillan.

O'Dwyer, B. and J. Unerman (2007). "From functional to social accountability: transforming the accountability relationship between funders and non-governmental development organisations." Accounting, Auditing \& Accountability Journal 20(3): 446-471.

Perry, L., \& Malkin, R. (2011). Effectiveness of medical equipment donations to improve health systems: how much medical equipment is broken in the developing world?. Medical \& biological engineering \& computing, 49(7), 719-722.

Polak, P. (2008). Out of poverty: What Works When Traditional Approaches Fail. San Francisco: Berrett-Koehler Publishers.

Porter, M. E., \& Kramer, M. R. (2011). Creating shared value. Harvard business review, 89(1/2), 6277.

Schweisfurth, M. (2011). Learner-centred education in developing country contexts: From solution to problem?. International Journal of Educational Development, 31(5), 425-432.

Slim, H. (2002). By what authority? The legitimacy and accountability of non-governmental organisations. The Journal of Humanitarian Assistance, 10.

Stiglitz, J. E., Sen, A., \& Fitoussi, J. P. (2010). Report by the commission on the measurement of economic performance and social progress. Paris: Commission on the Measurement of Economic Performance and Social Progress.

Strathern, M. (2000). The tyranny of transparency. British Educational Research Journal, 26(3), 309321.

Tacchi, J., J. Lennie and M. Wilmore (2010). Critical reflections on the use of participatory methodologies to build evaluation capacities in international development organisations. The 8th World Congress.

Taylor, J., \& Soal, S. (2003). Measurement in Developmental Practice: From the mundane to the transformational. Johannesburg,, South Africa: The Community Development Resource Association.

Thomas, A. (2006). "Design, poverty, and sustainable development." Design Issues 22(4): 54-65.

Vakil, A. C. (1997). "Confronting the classification problem: Toward a taxonomy of NGOs." World development 25(12): 2057-2070. 